\title{
Teacher and student interactions and characteristics from critical theorists school
}

\author{
Akbar Salehi \\ Department of philosophy of Education, Kharazmi university University, Iran
}

\begin{tabular}{l}
\hline \hline Article Info \\
\hline Article history: \\
Received Jan 25, 2019 \\
Revised Feb 28, 2019 \\
Accepted Mar 14, 2019 \\
\hline
\end{tabular}

Keywords:

Critical school

Critical theorists

Emancipation

Teacher - student relationship

\begin{abstract}
In recent years, critical thinkers have done serious discussions in education and other fields in our lives like social, cultural, political and economical. This paper is going to consider some of the critical thinkers' theories in order to clarify teacher and student interactions in education. The research is a type of fundamental and qualitative study which frames teacher and student interactions by means of a descriptive - analytical method. Accordingly, we introduce critical teacher as a teacher who includes specific characteristics like emancipation, critical nature and openness. Therefore mentioned teacher attends the role of culture in human life and he resists reproduced by the regime. He is someone who provides the way for public hearing; in addition, he teaches his students how to resist domination. On the other side, a student in this school will not be dominated by the regime by means of its essential tools as probe and questioning. A student has been taught to hear everyone regardless of race, religion and social class. Finally, this paper proposes applying these ideas for educational systems informal and operational ways.
\end{abstract}

Copyright $(2019$ Institute of Advanced Engineering and Science. All rights reserved.

\section{Corresponding Author:}

\author{
Akbar Salehi \\ Philosophy of Education Department, \\ Kharazmi University, \\ No 46 Khaghani Road, Darvazh Dollat, Tehran, Iran. \\ Email: salehihidji2@yahoo.com
}

\section{INTRODUCTION}

Critical theory has a broad history which addressing it in introduction isn't possible, but overall for this philosophical theory can consider the early and secondary philosophers. in the first category attention to the Mark's theory is focused, but recent category has had a special attention to the culture and overall we can know elders such as Aderno, Horkhaymr, Marcuse, Habermas as prominent representatives of first category [1] (for more study) see [2] and from recent category which has also special attention to education can note to the works of famous Brazilian trainer Paulo freire and people such as Appel, McLaren, Giroux, ... and others whom are counted as follower and expander of this aspect of thought of critical thinker. Whether this recent category has differences [3]claims it does not include a homogeneous set of thoughts but its common goal is strengthening the weak and overcoming inequalities and injustices [4]. on the other hand, both categories of these thinkers are postmodern and as [2] noted most effort of postmodernism is deconstruction from modernity.

The main goal of this article is analysis of some most famous thoughts of recent category about understanding the relation between teacher and student in view of this thinkers (second category) because the writer believes that we can pay to corollary and extraction of propositions which can draw ideal of this relation and at the end the critical school frameworks with reviews and wide entry of recent category in education.

As Ozmen and Kraver believe education has experienced postmodern scrutinizes and the most empowering fans of that were the critical theory followers and believe postmodern's thought understood a 
critical in culture and achieve this that never can use cultural tradition or single way of thinking as a meta narrative - universal sound for all human experience [4].

It's unlikely that critical school keyword in this research seem ambiguous and it mentions to two things but our goal was exactly both meanings, at first meaning of this keyword mentions more to the philosophers thought which in a one meaning are neo-Marxist and are from the followers of the Frankfurt School and in their works everyone has analyses education and its knowledge as part of a society culture but in second meaning the purpose of this keyword is the school same as a place to study from this angle critical school mentions the place where is different from the normal school, only place for education. in this school, concepts such as freedom of domination, non-racism, attention to differences, resort to listen to all voices and umbelliferous for all cultures and avoid reification are considered main goals which school wants to realize some of them and avoids some of other.

\section{CRITICAL TEACHER CHARACTERISTICS}

Freire knows the traditional education teacher as a knowledge transfer and the student as an acceptor [5]. he names banking concept of education in base of this type of relation and criticizes it too hard. Heyman [6] quoted from Freire that this approach in education are as considering empty ships of students that are accumulated by knowledge but the ability of critical thinking is withdrawn from them. Such an objective look at the knowledge leads to seeing world fixed [7]. In such situation the student only is expected to adopt herself with existing situation. Giroux and McLaren (see, [6]) consider this approach of banking to education the result of production of knowledge only in thought of teacher, trainer, theoretician and they believe that there isn't any news of challenging and interactive and critical discussions.

According to above topics and imported criticism, we can say briefly thinkers of this school value to the process of producing knowledge which is the result of discussion and critical dialogues that contains challenging discussions and their goal in this process is that teacher and student are only transfer and students aren't only acceptor of knowledge but also participates undeniable in production process.

In this regard, these thinkers expect to have certain expectations of the classroom as Giroux knows the classroom as radical place where has most potential. Florence [8] to achieve the new democratic community also knows the role of teacher's low but essential and vital critical teacher doesn't note only to the aspects of objective and experimental knowledge according to the basics of new lesson program but also explores aspects of it which cause critical understanding and freedom. on the other hand, he follows more basis question, question like this "why must this knowledge be learning?" more than follows knowledge gathering and classification and as Giroux [9] says, he makes the connection between facts and values so doesn't note to the experimental aspect of knowledge and reproves the traditional lesson program which doesn't choose this procedure and like as Howward Zinn claims this work is as drawing map with all the details on the ground.

Teacher evaluation in literature of this school and ideal drawing of this role also relate to considering some points. First a teacher can play the role of critical teacher perfect when him self has maximum participation with management in activities of school including decisions on administrative matters, lesson program, class. He/she does not have only the sense of operator but should see his role in making decision clear [10]. McLaren [11] believes that critical trainers have the ability of identifying structures and formal processes e.g. structure of schools and the rules of standards that learning situations and informal structures which set up students. This teacher as said before doesn't look positively to the Meta-narrative and them belief and teaches his students how looks critically to the metanarratives and analysis them.

On the other hand, he is an ongoing study, analysis and explanation teacher. He sees the differences well and wants to play his role in class and society in order to achieve social justice, eliminate discrimination very well. Another point which must be known about critical teacher is that he always injects hope to his classroom that means criticism and demonstrating the shortcomings don't blow passive mood in himself and his students but unlike he always seeks to achieve a pore for realizing his wishes on the other hand he knows the relation between current status and his considered utopia very well and this needs a lesson program which involves learner for achieving their wishes with current issues and at the same time also cheers them [12] Critical teacher pays special attention to the culture and its effects in human life and also it can be found in critical lesson program.

Reconstruction is also one of tasks that critical teacher considers for himself. He does reconstruction in text, on the other hand, although he does not forget the traditional knowledge but he pays to this subject that how text shapes our different ideas and brings the power in parts of community and reduces down other parts to the position of followers [4].

Int. J. Eval. \& Res. Educ. Vol. 8, No. 2, June 2019: 313 - 317 
Topics in this speech partly propel mind to this direction that critical school topics are dry and free of affection and feeling but this is a wrong look, in the literature of this school, love and hope have strong meaning and are considered as the basic components of realization of wishes. [3] The love in the Freire thought as power of love, introduced as:" something that makes Freire different from other leftist trainers is his emphasis on love, in his opinion, love is the most important component of talking and one of requirements of liberating education". He names love in Freire thought as revolution love which has commitment and loyalty feature for a universal liberation project.

\section{INTERACTION AND CHARACTERISTIES OF CRITITICAL STUDENT}

Zyngier [13] considers interactions and characteristics of students effective in their learning rate and raises three focused questions about axiology: what is the most valuable concept of interaction? What is the goal of this interaction and who its real beneficiaries? And at last how can we see student in discussion of social justice and also in leading scientific achievements with activating him?

According to it, student interact should be especial importance here [14]. he knows that he isn't only acceptor and he learn what is the goal of learning and what helps his /her learned for achieving his/her wishes.

Critical school student learns to use dialectic in line of enlightenment. with this look he learns and accepts that while he shows stamina in the face of the prevailing thoughts in government but also he should be ready to hear the talks from different languages and cultures and analyses them and surrenders to top ideas and it's obvious that this isn't surrenders, pure peremptory acceptance but it's an acceptance by thought and thinking and yet redeemer. So, it can be said student learns to not show special tenacity in entrancing to novel and new and even old and lost thoughts but instead of this when he must judge and choose the best, Giroux [9] [8] notes that critical education shouldn't be confused with self-indulgence. Individual and social needs should be led to the emancipation. Maybe one thing that makes this course and passing it easiest is the love that it was noted by Freire.

According to the frontier education of Giroux, Filips [15] believes when student wants to research about a problem, he should study confirmed cases of research and also rejection case of it and judges between them and makes choice.

It is such attitude that itself prevents dogmatism and unilateralism critical student in interacting with his teacher learns that always keeps away from two poles and should be between them is reification and another is dogmatism .first pole is the result of domination and raises his audience from various Hungarian in front of values and culture of best system passively and won't follow something for him expect devotion and passivity but when second pole will be achieved that audience, himself is of the ruling class or however he was became one of them and because of the effect of dogmatic pole he closes all ways in front of any talking and thought and he knows the thought which is dominated on him well and this is where he is captured by dogmatism.

By the same is talked, according to Baxter Magolda, Magolda, Peter [16] quotes: for being aware of others and their problems it's necessary to look at the issue from the angle of their view and it can be an opportunity for deep understanding of others and increasing patience and preventing dogmatism.

Although critical school student follows acquiring knowledge but always considers that his taking knowledge isn't passively and he doesn't act passively against learned knowledge but he uses knowledge and everything which learns and reserves, for realization of social justice and becoming to act and elimination of discriminations and contradictions. Hence, we can say critical student has revolutionary spirit so he doesn't take political and ideological boundaries as hard and permanent boundaries.

Giroux [10] while says about being beneficiary of students also notes this point that opportunity for going beyond of political and ideological boundaries should be provided for him.

Giroux (quoted from Heyman) [6] calls citizens as social players, he says we shouldn't suffice to giving lecture and like it but we should practice knowledge, skill, habits of critical citizen actively in classroom. Heyman [6] knows the critical education as treatment of students that they are only users of knowledge until now and after this time they will become effective factors in producing it and he sees all this process in a class that Giroux called it "vital public space ".

Also, praxis (intellectual action) has special and prominent position with companions of critical school. maybe we can describe this act as an operation that student and even critical teacher consider it for being wise, fairness, useful for public before entry a work and this is itself a barrier for preventing operations that aren't wisely and don't have strong reasonably support also it should be noted when speak about refusing government and acceptance of political and ideological boundaries and social classes it doesn't mean that teacher and student of this school want to refuse rules or pulling the society into chaos by unfounded challenges but it means critical teacher and student want to remove these issues and problems by deep 
thinking and understanding the hidden issues which realize the domination slowly [17]. He really notes to morality and never accepts that he used every tool for achieving to these sacred ideals.

\section{CRITICAL SCHOOL PROPERTY}

The most important characteristics of critical teacher and students will be explained briefly then we should address this issue that these can't achieve success alone but also school environment should have properties and helps this interaction. Apple [18] notes while schools claim the democratic principles but in practice is involved by market capitalism and this is a reason that because youth will lead to the social inequalities and genders and injustices.

Giroux [10] believes that we should not consider schooling as a closed system. But unlike should look at it as dynamic system and happening system and he believe that this property leads teacher towards creativity. he knows upbringing the result of gathering people for discussing question and finding answer and also he knows the relationship between teacher and managers as the effective factor in this important issue and believes that both this two groups must have mutual understanding about their relationship and must know their responsibility towards and he claims the quality of this relationship relates to the quality of questions and the quality of openness in such questions between the two groups and their honesty and willingness[19]. But he believes that the current class structure doesn't provide such a possibility for these two groups [20].

Important point which great trainer Freire notes it, that school isn't separated and isolated environment and from society (is quoted from Giroux 1981) [9]. it means that school is part of society and it's effective in it there is such looking to the school which can works in framework and design of critical school that its goal isn't only transferring information. Giroux [21] introduces democratic as a moral ideal suggests for achieving freedom, equality, fraternity learning should be shaped according to ethical commitment to the ethical challenges and introduce students deep understanding from their wise , civil , moral role as a broker and it should be seen in school lesson program .so from this view school will be a place for justice realization and tracking the justice demands but also we should be careful about this that after this claim school don't become a place for injustice promotion but as Giroux quotes from Dryad : it is possible that each profession and industry claim about justice one day will become the axis of injustice because of this view school/university will become a place for thinking (thinking without condition ) or at least a think tank for youth and give them the ability of future evaluation [22]. Heyman [6] quoted from Giroux that the goal of critical education is nurture of critical citizens whom can power on their life on the other hand; critical school is same as democratic school. The school which the citizens are nurtured in it that differences are important for them and want to reach agreement.

This school is a democratic school that main goals of it critical utopia education [3] they name this school 'perfectible site 'that it doesn't need denying the opposition for realization and making and in these can hope to citizens' education that said before [11]. Also, Brown [23] believes: democratic schools always don't include and cover the top-class interests. The meaning of Brown seems de-monopolization that can be considered one of other properties of such schools .no doubt desensitization monopoly schools needs teacher and program more than anything else. Especially a lesson program that clear aspects and also cache aspects of that lesson program isn't unique in a special class.

\section{CONCLUSION}

Afterward is that their elements of education system namely, critical teacher, critical student, critical school are as a puzzle that the components coordination can bring resistance against metanarrative which is one of important characteristics of critical teacher and also his/her students. Also, because they are advocate of critical education, surely will make commitments to oppressed

Language of empowerment which exists in some thinkers of this field is another tool for realization of their wishes. Strong language is taking by a dialectic that is established in talks of teacher-student, teachermanager and finally student-government and itself is a tool for injustice brush-off. teacher and student interaction and even lesson program as an important component of a school for achieving goals that said it isn't possible without being rich of love and hope in this relation love promises the desire to knowing and achieving goals and the hope of passing the failures and barriers.

At the end, critical student should learn resisting against any domination and also against thoughts that want to reproduce the relations which their eventual isn't except domination and this is possible by making appropriate backgrounds in educational systems and also political systems. On the other hand, until a government does not believe hard criticism and of course fair, we can not expect such environment.

Int. J. Eval. \& Res. Educ. Vol. 8, No. 2, June 2019: 313 - 317 


\section{ACKNOWLEDGEMENTS}

I acknowledge for all over my peers in university of Kharzami in department of philosophy of education, especially for associated Professor Ali Reza Mahmudnia, head department of philosophy of educationin, Kharzmi University.

\section{REFERENCES}

[1] Giroux, H, "A' critical theory and schooling: implications for development of a radical pedagogy," Discourse: Studies in the Cultural Politics of Education, vol. 3, no. 2, pp. 1-21, 1983.

[2] Stanley Aronowitz., "Theory and Socialist Strategy.," Social Text, (Winter, 1987), no ,16 pp. 1-16, 1987.

[3] McClaren, P., "A Pedagogy of Possibility: Reflecting upon Paulo Freire's Politics of Education: In Memory of Paulo Freire," Educational Researcher, vol. 28, no. 2 (Mar., 1999), pp. 49-56, 1998.

[4] Beheshti S, Reflection and criticism in the philosophy of education in the contemporary world, Tehran: information press 1386 (chapter,31,32) Persian

[5] Freire, P., Pedagogy of the Oppressed. New York: Continuum, 1970.

[6] Heyman, R, "Why Advocacy Isn't Enough: Realizing the Radical Possibilities of the Classroom," International Research in Geographical and Environmental Education, vol. 10, no. 2, pp. 174 - 178, 2001.

[7] Payne, M., Barbera, J. R., A dictionary of cultural and critical theory. (2nd ed.). United Kingdom: WileyBlackwell. 2010

[8] Florence, N., bell hooks' Engaged Pedagogy. Westport, CT: Bergin \& Garvey,1998.

[9] Giroux, H., Anthony Penna and William Pinar (eds.). "Curriculum and Instruction 1981", (Toward a New Sociology of Curriculum.)" In Henry Giroux, et.al. (ed.), Curriculum and Instruction, op. cit, pp. 98-108.)

[10] Giroux, A, H., "Schooling as a Process: The Role of Dialogue in Education," Clearing House, 50, pp. 20-23, 1976.

[11] McLaren, P., Life in Schools: An Introduction to Critical Pedagogy in the Foundations of Education. New York:. Routledge 2015.

[12] Fischman ,G, E. and McLaren, p., "Schooling for Democracy: Toward a Critical Utopianism Contemporary Sociology, vol. 29, no. 1, 2000. Utopian Visions: Engaged Sociologies for the 21st Century pp. 168-179.

[13] Zyngier, D, "listening to teachers-listening to students: substantive conversations about resistance, empowerment and engagement," Teachers and Teaching, vol. 13, no. 4, pp. 327-347, 2007.

[14] Zyngier, D, "Re-conceptualizing student engagement: Doing education not doing time." Journal of Teaching and Teacher Education, vol. 24, pp. 1765-1776, 2008.

[15] Phillips, R "Contesting the Past, Constructing the Future: History, Identity and Politics in Schools", British Journal of Educational Studies, vol. 46, no. 1, pp. 40-53, 1998.

[16] Magolda, P, "Border Crossings: Collaboration Struggles in Education", The Journal of Educational Research, vol. 94: 6, pp. 346- 358, 2001.

[17] Hooks, B, teaching to Transgress. Education as the practice of freedom, London: Routledge. $216+x$ pages. Draws on Freire but looks to developing a feminist, engaged pedagogy relevant to multicultural contexts. 1994.

[18] Apple, M,.Cultural Politics and Education. New York: Teachers College Press, 1996.

[19] Aronowitz, Stanley, and Henry Giroux. Postmodern Education: Politics, Culture and Social Criticism. Minneapolis MN: New York, University of Minnesota Press, 1991.

[20] Giroux, H., Border crossings: Cultural workers and the politics of education, New York: Routledge. 2005.

[21] Giroux, H, A,"Beyond the Ethics of Flag Waving: Schooling and Citizenship for a Critical Democracy," The Clearing House: A Journal of Educational Strategies, Issues and Ideas, vol. 64: 5, pp. 305 - 308, 1991.

[22] Giroux, H and Susan, S., Between race and reason, Violence, Intellectual Responsibility, and the University to Come, California: New York Stanford university press, 2010.

[23] Boron, A. Transition Toward Democracy in Latin America, Mimeograph, 1992.

\section{BIOGRAPHY OF AUTHOR}

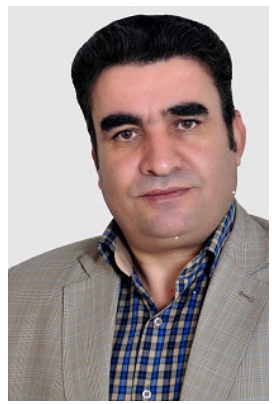

Dr. Akbar Salehi is faculty member in philosophy of education, Kharazmi University in Tehran, Iran. He teaches critical pedagogy, philosophicacal foundation. He wrote and translated eight books and many article in Persian and English language in the area philosophy of education, Islamic education, and ethichs. 